\title{
Legal Protection To The Public Notary In Providing
}

\section{Information Before The Investigation}

\begin{abstract}
Hanif Dzaki ${ }^{1}$ and Lathifah Hanim ${ }^{2}$
Abstract. A Notary is a Public Officer authorized to make an Authentic Agreement which has other powers as regulated in UUJN or under any other Law. Authentic Agreement aims to be used as powerful or perfect evidence if there is any occurrence of a dispute between the parties or there is a lawsuit from the parties. The method used in this study was sociological juridical method with descriptive analytical research specification, while the data analysis method used qualitative analysis. Based on the results of research and discussion, it can be concluded that the legal protection to the Notary in conducting a call by the investigator is conducted through the process in accordance with applicable legislation. Notary's call by the investigator shall be made with the prior approval of the Notary Honorary Council. It is as regulated in Article 66 UUJN. Other forms of legal protection that can be granted to a Notary are by supervision, attaching fingerprints and legal protection provided by the Indonesian Notary Association as the sole organization of Notary in Indonesia. Constraints faced by the Notary in executing summoning by the investigator are, the calling process which requires a long process and must be through the priority of the Notary Honorary Council in advance resulting in less effective time. So the solution is to conduct a more effective investigation by doing a good cooperation between the investigators, Notaries, Notary Honorary Council, and the Indonesian Notary Association.

Keywords: Legal Protection; Public Notary; Agreement; Investigator.
\end{abstract}

\section{Introduction}

Notary is a very noble profession, because the role of Notary is very important for the life of the community, so the behavior and the act of Notary in running his position must be in accordance with the Notary's code of ethics. Notary has a Professional Ethics where Professional Ethics is a special Moral Ethics created for the good of the profession concerned. Each profession has certain characteristics as identity, the nature of the profession standard itself is in accordance with their respective professions. $^{3}$

Based on Article 1 Sub-Article 1 of Law of the Republic of Indonesia Number 2 Of 2014 concerning Amendment to Act No.30 Of 2004 Concerning Position of Notary (hereinafter referred to as UUJN) it is stated that a notary is a Public Official authorized to create an Authentic Agreement with other authority as stipulated in this Law or under any other Law. Authentic Agreement aims to be used as powerful or perfect evidence if there is any occurrence of a dispute between the parties or there is a lawsuit from the parties. If there is a dispute from the people the notary has work with, it is possible for the notary to take a part to the dispute. ${ }^{4}$

\footnotetext{
${ }^{1}$ Student of Master Program (S2) of Notaries Faculty of Law UNISSULA Semarang Indonesia email : ahmadpitek@gmail.com

${ }^{2}$ Lecturer of Faculty of Law UNISSULA

3 R. A. Emma Nurita 2012 Cyber Notary Refika Aditama Bandung p. 1-3

${ }^{4}$ Muhammad Ilham Arisaputra September 2012 Kewajiban Notaris Dalam Menjaga Kerahasiaan

Isi Akta Dalam Kaitannya Dengan Hak Ingkar Notaris Perspektif Volume XVII No. 3
} 
Notary has the authority to determine an act can or may not be contained in the agreement. Before making such a decision, the Notary must first consider and review all documents provided, then examine them, and hear statements from the parties. Considerations and decisions given by the notary must be based on the legal aspects and consequences that will arise in the future. Notary in his/her position must be in accordance with the corridor specified in UUJN (Public Notary Law), notary code of ethics, and other regulations. However, in reality, there are still many notarial agreements in question by the parties and the cause of the conflict arising from the agreement may be from the notary's or the parties' mistakes. ${ }^{5}$

As a form of the duties and obligations of Notary Public, it is required that a Notary must have good quality science, behavior, faith, devotion and must uphold the nobility of prestige and dignity as a notary in providing professional and good service for the community. If a Notary is not able to provide professional services and good for the community, it is not impossible that many parties who feel aggrieved as a result of the service. In addition, the Notary must also be able to provide clear and correct information for the community. Not only as the author of the Authentic Act, but the notary is also a legal consultant for the community. Providing clear and correct information that aims to avoid claims of misrepresentation and avoid misleading information. Notary plays an important role in society, the notary has the position as the only public official authorized in making authentic agreements.

The definition of authority here is authorized to the person, ie for the interest of whom the agreement is made or desired by the interested parties. Authority to the Act shall be the person authorized to make an authentic agreement of all acts, treaties and statutes prescribed by law or by the parties concerned. Authority to the time and place, that is in accordance with the place of position and the territory of the notary office and to guarantee the certainty of the time of the constituents listed in the agreement. ${ }^{6}$ The authentic agreement contained in Article 1868 of the Civil Code is a agreement made by officials authorized for it by the government according to the law. Authentic agreements have 3 (three) forms of evidentiary power: ${ }^{7}$

- The power of formal proof

To prove the certainty that an event and fact in the agreement is true by a notary and explained by the tapers listed in the agreement according to the applicable procedure;

- The power of material proof

To prove the parties that the incident in the agreement happened in a real way; and

- Strength binding

Prove that the parties and third parties, that on that date have faced and explained in the written agreement.

Practice in the field, it is often occur that the Notary is involved in civil or criminal disputes in the agreement. Such disputes may be caused by the actions of the parties facing the agreement, then report to the authorities such as the police or the prosecutor's office. Based on the report, the investigator will give a letter to the notary. But in the process of calling, it must be with the approval of the Local Notary Public

\footnotetext{
5 Pingkan Sundah May 2014 Tinjauan Yuridis Terhadap Tidak Dilaksanakannya Kewajiban Jabatan Notaris Menurut Undang-Undang No. 2 Tahun 2014 Lex et Societatis Vol. II No. 4

${ }^{6}$ Habieb Adjie 2009 Meneropong Khasanah Notaris dan PPAT Indonesia PT. Citra Aditya Bakti Bandung p. 14

7 Habieb Adjie 2008 Sanksi Perdata dan Administrasi Terhadap Notaris sebagai Pejabat Publik Rafika Aditama p. 72
} 
Honorary Council (hereinafter referred to as NHC), it is in accordance with UUJN (Public Notary Law). It is different from the Constitutional Court Decision No.49/PUUX/2012 which has reduced the protection of the Notary due to the removal of the phrase NHC (Notary Honorary Council) approval, so that in the calling of Notary by the investigator without the approval of NHC Territory.

After the issuance of the Constitutional Court Decision No.49 / PUU-X / 2012 when the notary is called for the purpose of investigation, trial or other purposes of the investigator, there may be a violation of the rights of others because the parties have entrusted all the information that the notary must keep secret. Therefore, the notary public does not have a legal protection in giving information to investigators or other law enforcers.

Before the birth of UUJN, the supervision of the notary was conducted by the Judicial Board, after the enactment of UUJN, the supervision is done by the Ministry of Law and Human Rights (KEMENKUHAM). It then formed the Notary Honorary Council (NHC) authorized to carry out coaching and give approval or refusal for the interest of investigation in the judicial process. As the implementer of the regulation as stipulated in the Regulation of the Minister of Justice and Human Rights of the Republic of Indonesia Number 7 Of 2016 (hereinafter referred to Permenkuham No. 7 of 2016).

In order to avoid notaries from legal cases, the Indonesian Notary Association (INA) seeks to play its role as a notary organization with the effort to improve the knowledge, skills and performance of a notary. This is because it is not fully understood by the notary's position and consequently according to UUJN and Memorandum of Understanding (MoU) which has been signed by all notaries with the Police of the Republic of Indonesia concerning the procedure and process of notary calling.

With the new regulations, at least the notary is slightly calmer because of the form of legal protection in performing their duties as Public Officials. It will be more secure against arrest, detention, or investigation by the investigator, since the action is carried out after examination and research conducted by the Notary Honorary Council which may also impose sanctions on the notary.

\section{Research methods}

This study used sociological juridical approach. In other word, this research used social legal research approach, Tamahana stated that socio-legal studies are addressed to Law and Society Studies ${ }^{8}$ It investigated at first by using secondary data that is library material then continued with research to primary data obtained from field observation. It was done by paying attention to applicable law norm connected with facts which met from research.

Research specification used was descriptive analysis, that is describing problem then analyze the existing problems through data collected, processed, and arranged based on theories used. This research was expected to obtain a clear, detailed, and systematic description by analyzing data to solve the problems in accordance with applicable law.

This research method used field study type (primary data) and literature study (secondary data). In performing data analysis, the authors used qualitative analysis methods, namely a research procedure. It is descriptive data analysis procedure.

\footnotetext{
${ }^{8}$ Anis Mashdurohatun, Redyanto Sidji, Gunarto and Mahmutarom, Factors Causing Banking Cyber Crime in Indonesian, International Journal of Economic Research, Volume 14 Number 15 2017, p.295
} 
Descriptive data analysis is the collected data that does not use the numbers and measurements, so what the respondents stated in writing or oral and who researched and studied as something intact.

\section{Result And Discussion}

\subsection{Legal Protection against Notary in Calling Procedure by the Investigator}

Authentic agreements constitute evidence for the parties to an agreement which contains the rights and obligations of the parties in respect of matters agreed upon. Therefore, authentic agreements are useful to the parties to ensure their rights and obligations for the sake of legal certainty, order, and legal protection for the parties concerned and also for society as a whole. The authenticity of the agreement survives even if the Notary makes him/her dead. The Notary's signature shall remain in force even though he can no longer convey information about the events at the time of the act of agreement. ${ }^{9}$

There are 2 (two) types of notarial agreement namely Agreement made by (door) Notary in practice Notary is called Agreement of Relaas or Agreement of Minutes which contains in the form of description Notary seen and witnessed by Notary at the request of the parties. In order to the actions of the parties shall be poured into the form of notarial agreement; Notarial agreements made before Notary Public (ten overstaan). In the practice, it is called as a Agreement of the Party, containing a description or statement, a statement of the parties given or told before a Notary. The parties wish that their description or statement be poured into the form of Notary agreement. ${ }^{10}$

With regard to the responsibility of the agreement made before the Notary, it should be emphasized that with the authority of Notary in the notarial agreement, it does not mean that Notary can freely, according to his intention, to create an authentic agreement without any parties requested to make the agreement. ${ }^{11}$

The law has arranged for every capable person to be a witness, obliged to give testimony before the court, both in civil cases and criminal cases. The rights owned by a Notary in relation to a criminal case cannot be used, because before the law every good citizen is obliged to give true testimony and nothing else than the truth. And in this case, the role of the judge is necessary whether the Notary is necessary or not in giving testimony in the judicial process.

So far in the process of calling, a Notary by the interests of the investigator must first through the permission to NHC (Notary Honorary Council). For the first step, NHC calls the Notary, checks whether it is true that the Notary is in violation of his/her position which is not in accordance with UUJN, Code of Ethics, and other regulations governing it. If the NHC judges the notary to be non-infringing then NHC does not allow investigators to check the Notary. Conversely, if the NHC judge a notary is inagreement a violation, then $\mathrm{NHC}$ will allow investigators to check the notary. (Interview with Ms. Setyawati, June 29, 2018).

The summons shall be issued no later than 3 (three) days from the date of receipt of the summons as recorded in the receipt to prepare the notary to collect the necessary data and materials. If a notary who is summoned for legal reasons does not meet the investigator's inquest, the investigator may come to the office or residence of the

\footnotetext{
${ }^{9}$ Habib Adjie op.cit. p. 43

${ }^{10}$ G.H.S. Lumban Tobing 1992 Peraturan Jabatan Notaris Erlangga Jakarta p. 51

11 Ismantoro Dwi Yuwono 2011 Memahami Berbagai Etika Profesi dan Pekerjaan Pustaka Yustisia Yogyakarta p. 193
} 
notary who is called to conduct an inspection as provided for in Article 113 of the Criminal Procedure Code.

Some practices that make the importance of legal protection for Notaries are:

- Notary who is filed and summoned as a court witness concerning the agreement he made and become the evidence in a case;

- Notary become a defendant in the court concerning the agreement which he made and considered to be detrimental to the defendant;

- Notary as defendant because it is assumed to assist the act of counterfeiting agreement done by the party making the agreement to the notary; and

- Confiscation of Notary's bundle of ministers with NHC approval.

Legal protection for Notaries has been normatively given by applicable laws and regulations, namely:

- The establishment of the Supervisory Board as mentioned in Article 67 of the UUJN shall be established by the Minister consisting of 3 (three) elements, they are: 3 (three) persons from the government, 3 (three) persons from the Notary organization, and 3 (three) academics. Such supervision involves the execution of a Notary's office;

- Regarding the procedure for taking the Minutes of the agreement and invoking the Notary, pursuant to Article 66 of the UUJN stating that for the sake of the judicial process, the investigator, the public prosecutor or the judge with the approval of the Notary Board of Notary (NHC), the Authorized Notary in the examination relating to the agreement he made and took copies of the Minutes Agreement and the letters attached to the Minutes Agreement;

- Right of right of non-disclosure Notary (verschoningrecht, Hak Ingkar) as regulated in: (1) Article 170 of KUHAP; (2) Article 1909 point 3 of the Civil Code; (3) Article 4 paragraph (2) UUJN and (4) Article 16 paragraph 1 letter (e) UUJN; and

- Decision of the Central Supervisory Board Number C-MPPN.03.10-15 concerning the Granting or Rejection of the Notary's Calling Agreement by the investigator, public prosecutor and judge.

UUJN (Notary Public Law) is a legal product to provide legal certainty and protection for the Notary in performing his profession as the Public Officer of the Authentic Agreement Authority. The forms of legal protection to the Notary are as follows:

- The provisions governing the disobedience and disgrace of a Notary listed in Article 4 paragraph (2), Article 16 paragraph (1) subparagraph $f$ and Article 54, Habib Ajie refers to the right of repudiation as a "Non-compliance obligation". He explains that one part of the Notary's pledge is that the Notary will keep the contents of the agreement and the information obtained in the execution of the Notary. Notary has the obligation to conceal everything concerning the agreements he made and all information obtained for agreements in accordance with the oath/pledge of office, except for other determining laws;

- Fixed the fingerprint in the minutes agreement as stipulated in Article 16 paragraph (1) letter c. It is the duty of NHC to provide supervision to Notary when examining the completeness of supporting documents of the agreement. Fingerprint function to strengthen evidence. Thus, it is hoped that attaching fingerprints can give legal protection to Notary;

- Protection of Notary as member of Indonesian Notary Association. This association provides protection for the Notary in respect of the profession and his position as Public Officer. As a core objective, INA (Indonesian Notary Association) cooperates with the police agency through a memorandum of understanding between him and the Indonesian National Police Number 01/Mou/PP-INI/V/2006 mentioning that to 
regulate the guidance and professional development in the legal field for notary public related to the secret of office as profession based on trust. The memorandum of understanding is an ordinance to be performed if the Notary is called by the police;

- The NHC Agreement pursuant to Article 66 of the UUJN stipulates that in order to be called, a Notary must be with the approval of NHC first. The examination conducted by NHC in accordance with Article 70 letter a UUJN, by holding a hearing to check the existence of infringement rate by the Notary. After the examination by $\mathrm{NHC}$, then the examination will be poured to a decree that contains approval or rejected the request of the investigator. The NHC must have a clear reason if it receives the approval of the investigator, as well as the refusal. (Interview with Ms. Setyawati, June 29, 2018); and

- NHC receives an approval letter by the investigator within 30 days. If the letter has no response then the Notary is directly summoned by the investigator, then NHC immediately coordinate with the investigator. Notary who is proven to be a violation, NHC gives approval to summon the notary by the investigator. Notary who fulfill the call of investigator usually remain accompanied by Indonesian Notary Association local area. But here, this association does not act as an advocate, but provides moral support and as a companion to the case facing Notary. (Interview with Ms. Setyawati, June 29, 2018).

\subsection{Constraints Faced by Notary in the Implementation of Calling by Investigator and The Solutions}

Dealing with Notary's case, the Investigator, his capacity in conducting investigations faces obstacles in examining the Agreement made by Notary to prove that the Agreement can criminalize the Notary. The obstacles are from the internal Investigators as well as from the external Investigators as follows:

- Since the calling for a Notary must go through a longer process, it makes a negative assumption against the investigator because in general the reporting party does not understand the specific procedures that the investigator must take to present the Notary as a witness or suspect.

- In conducting investigations, usually, the investigator handle the problem of criminal case, so here the investigators have better understand the issue of criminal law. On the other hand, Notary makes an Authentic Agreement of agreement in the matter of Civil, the investigator often experience errors in applying Article. Whether the investigator will use civil cases or criminal case.

- The notary requested by his presence as a witness or suspect. The notary seems to avoid coming in the process of investigations for various reasons, and only his employees representing Notary Protocol and lawyers authorized by Notary in this case are not the names expressly mentioned in the summons attending.

- There is a difference of opinion between the police investigator and the Notary that the Notary assumes that his work is only performing the duty by making the agreement desired by the parties in the form of Authenticity, so as to have legal certainty for the parties and if any loss suffered by either party is not the responsibility of Notary because from the beginning the agreement was made by mutual agreement that is agreement in civil area so that it cannot be prosecuted for criminal case.

- Notary is not willing to be examined because of questions from the investigators are not focused on the problem. It means the investigators do not understand the authority and responsibility of Notary, such as the right of non-disclosure owned by 
Notary. In some cases, the notary has answered the question, but the investigator still keep asking with questions which makes the Notary feel like a suspect who has made a mistake in Criminal Acts, this is because the investigator does not know the authority that is in the Notary ie the Notary Agreement will bind the parties concerned in the Agreement if the making of the Agreement:

- Authorized to make the Agreement in accordance with the wishes of the parties; and

- Outwardly, formally and materially in accordance with the rule of law on the making of Notarial Agreement, the Agreement is considered valid. Assessment of Notary Agreement as the product of Public Official of the assessment shall be conducted on the basis of the legal presumption, that the Notary Agreement should be deemed valid until the Court Decision has a permanent legal power, the Notary Act shall be valid and binding on the parties concerned.

With the existence of several constraints, then there must be a solution to overcome. They are as follows:

- As a Notary, if he/she called by an investigator who has obtained permission from $\mathrm{NHC}$ both the capacity as a witness and suspect must remain proactive and come to be asked his statement. With the issuance of a new Notary Law, the Notary come in accordance with the summons to the Notary concerned and the investigating party shall summon the Notary by fulfilling all the procedures of calling and examining the Notarial Agreement.

- The investigator is requested when examining the Notary must be in accordance with the cases handled according to the authenticity of the Agreement which made the element of uniformity also internally Notary Code of Ethics as mandated by Act No.2 Of 2014.

- It is hoped that between Police and Notaries to be socialized up to their respective jurisdictions, so that Notaries as Public Officials appointed by the government and investigators as protector, guidance, and service to all public interest. To hold a periodical meeting at least once a year made in a relationship, so that the notary and the investigators know each other in the respective duties because both stakeholders provide services to the community. So that people are served, protected and respected what their willingness and their wants to cooperate with each other. Since without the citizens, investigators and Notaries cannot work, and vice versa without the Notary, the public will not get legal certainty in making the agreement

\section{Closing}

\subsection{Conclusion}

- Legal protection shall be granted to anyone, including Notary as an Indonesian Citizen. Legal protection against Notary in the judicial process is done through the process in accordance with the prevailing laws and regulations. With the use of disgrace or obligation of non-compliance of Notaries or invitation of Notary by the investigator, prior approval from NHC shall be made. It is as regulated in Article 66 UUJN. Another form of legal protection that can be granted to a Notary is by supervising, attaching fingerprints and legal protection provided by Indonesian Notary Association as the only notary organization in Indonesia.

- Obstacles faced by the investigator in discovering the truth of the contents of the Agreement made by Notary in accordance with the limit of Notary Agreement can 
be used as a basis for criminalizing Notary. The existing obstacles from both parties, the investigators themselves because they do not understand the civil scope and the notary scope as well as repeated calling the Notary, these issues give such impression that notary is unwilling to be investigated. On the other hand, the calling of Notary to be investigated also takes a long time process, because it has to go through the approval process of Notary Honorary Council based on Act No.2 Of 2014 about UUJN but Honorary Council.

\subsection{Suggestion}

- Preferably between the investigating parties and the Indonesian Notary Association establish good relations with each other by carrying out their respective obligations, meaning that the Notary when called in the examination should spend time in meeting the summons of the investigator. While the investigator should appreciate the time spent by Notary with a more effective examination, so as not to waste time.

- We recommend that NHC provide more supervision to every Notary, so that each Notary is more aware of the law and do not often make mistakes that result in violations. It can harm a particular party and can even be caught in a criminal case.

\section{References}

[1] Anis Mashdurohatun, Redyanto Sidji, Gunarto and Mahmutarom, Factors Causing Banking Cyber Crime in Indonesian, International Journal of Economic Research, Volume 14 Number 152017

[2] G.H.S. Lumban Tobing 1992 Peraturan Jabatan Notaris Erlangga Jakarta.

[3] Habieb Adjie 2008 Sanksi Perdata dan Administrasi Terhadap Notaris sebagai Pejabat Publik Rafika Aditama.

[4] Habieb Adjie 2009 Meneropong Khasanah Notaris dan PPAT Indonesia PT. Citra Aditya Bakti Bandung.

[5] Ismantoro Dwi Yuwono 2011 Memahami Berbagai Etika Profesi dan Pekerjaan Pustaka Yustisia Yogyakarta.

[6] Muhammad Ilham Arisaputra September 2012 Kewajiban Notaris Dalam Menjaga Kerahasiaan Isi Akta Dalam Kaitannya Dengan Hak Ingkar Notaris Perspektif Volume XVII No. 3

[7] Pingkan Sundah May 2014 Tinjauan Yuridis Terhadap Tidak Dilaksanakannya Kewajiban Jabatan Notaris Menurut Undang-Undang No. 2 Tahun 2014 Lex et Societatis Vol. II No. 4

[8] R. A. Emma Nurita 2012 Cyber Notary Refika Aditama Bandung. 